\title{
Physiological and biochemical aspects of 'Tommy Atkins' mango subjected to doses and methods of application of paclobutrazol
}

Aspectos fisiológicos e bioquímicos da mangueira 'Tommy Atkins' submetida a doses e formas de aplicação do paclobutrazol

\author{
K. M. Ferreira' ; W. L. Simões ${ }^{2}$; M. A. C. Mouco² J. R. Silva² ; A. C. Mesquita ${ }^{1 *}$ \\ ${ }^{l}$ Departamento de Tecnologia e Ciências Sociais/Laboratório Fisiologia Vetetal, Universidade do Estado da Bahia, \\ 48904-711, Juazeiro-BA, Brasil \\ ${ }^{2}$ Embrapa Semiarido, 56302-970, Petrolina-PE, Brasil
}

*alessandro.mesq@yahoo.com.br

(Recebido em 29 de maio de 2020; aceito em 30 de outubro de 2020)

\begin{abstract}
The paclobutrazol has been widely used to stimulate the flowering of mango trees, regulating vegetative growth and promoting changes in photosynthetic activity and in the production of photoassimilates. In this context, the objective of this study is to evaluate the effects of forms and doses of PBZ on the biochemical and physiological variables of mango, cultivar 'Tommy Atkins,' in the Brazilian semiarid region. The experimental design was randomized blocks in a $5 \times 2+1$ factorial design with the first factor was paclobutrazol doses applied by irrigation $\left(0.5,1.0,1.5,2.0\right.$ and $2.5 \mathrm{~g}$ a.i. ${ }^{-1}$, linear canopy); the second factor was two phases of collection (vegetative and flowering), and an additional treatment (control) with the application of a dose in the conventional form ( $2.0 \mathrm{~g}$ a.i. ${ }^{-1}$ linear canopy applied manually by haul), and four replications. The variables analyzed were levels of total soluble sugars, reducing sugars, non-reducing sugars, total amino acids, total soluble proteins, liquid photosynthesis, stomatal conductance, transpiration, and leaf temperature. The application of PBZ by fertigation proved more efficient than the conventional application, allowing a greater assimilation of the product by the plant and the reduction of the dose. Most biochemical characteristics showed the highest values by applying lower doses of paclobutrazol. The increase in paclobutrazol doses applied by irrigation system reduced the gas exchange of the 'Tommy Atkins' cultivar.

Keywords: Mangifera indica L. PBZ, gas enchange
\end{abstract}

O paclobutrazol tem sido amplamente utilizado para estimular o florescimento da mangueira, regulando o crescimento vegetativo, promovendo alterações na atividade fotossintética e na produção de fotoassimilados. Nesse contexto, objetivou-se com este trabalho avaliar o efeito de formas e doses de PBZ nas variáveis bioquímicas e fisiológicas da mangueira cultivar Tommy Atkins no semiárido brasileiro. $\mathrm{O}$ delineamento experimental foi em blocos casualizados em esquema fatorial $5 \times 2+1$, sendo o primeiro fator, doses de paclobutrazol aplicadas via sistema de irrigação $\left(0,5 ; 1,0 ; 1,5 ; 2,0\right.$ e 2,5 g i.a.m ${ }^{-1}$ linear de copa), o segundo duas fases de coleta (vegetativa e floração) e um tratamento adicional (controle), com a aplicação de uma dose na forma convencional ( $2,0 \mathrm{~g}$ i.a. $\mathrm{m}^{-1}$ linear de copa aplicada manualmente a lanço), com quatro repetições. As variáveis analisadas foram os teores de açúcares solúveis totais, açúcares redutores, açúcares não redutores, aminoácidos totais, proteínas solúveis totais, fotossíntese líquida, condutância estomática, transpiração e temperatura foliar. A aplicação do PBZ via fertirrigação mostrouse mais eficiente do que a aplicação convencional, possibilitando uma maior assimilação do produto pela planta e permitindo a redução da dose. A maioria das características bioquímicas, apresentaram os maiores valores médios com a aplicação de menores doses de paclobutrazol. $\mathrm{O}$ aumento das doses de paclobutrazol aplicadas via sistema de irrigação, reduziu as trocas gasosas da mangueira cultivar Tommy Atkins.

Palavras-chave: Mangifera indica L. PBZ, trocas gasosas

\section{INTRODUCTION}

Mango (Mangifera indica L.) is one of the most important tropical fruits grown worldwide. Brazil, in addition to being self-sufficient in the production of mango, is one of the largest 
exporters of the fruit, with 179 thousand tons exported in 2017 and revenue of more than US\$ 205 million [1].

The mango orchards of the medium course of Vale do São Francisco are one of the main productive chains of Brazilian fruit production. The use of efficient technologies associated with private entrepreneurship marks the region due to its high productivity, fruit quality and the planning of crops to be harvested at any time of the year [2]. This is only possible, among other factors, due to the use of phytoregulators that allow flowering control, being the paclobutrazol (PBZ) the most used for this culture.

The PBZ is a plant regulator that inhibits the biosynthesis of gibberellins, restricts vegetative growth, and induces flowering [3]. In addition, the application of PBZ can influence other characteristics of mango, such as increasing the concentration of carbohydrates and proteins [4] and changing photosynthetic activity [5].

Different responses to the application of PBZ are obtained in mango crops depending on climate, nutrition and plant age [6]. The dose and form of application also influence the response of plants to PBZ $[5,7,8]$. In this case, the challenge has been to identify the appropriate dose and method of application [5,9], since an overdose can cause undesirable effects, such as growth delay, panicle malformation and reduction in the vegetative and root growth of mango trees [10].

The application of PBZ by irrigation system has been tested by some producers in the middle course region of the São Francisco Valley. However, there is no technical validation for the cultivation of 'Tommy Atkins' mango, which is one of the most cultivated cultivars. Thus, studies on the doses of PBZ and different forms of application are necessary to obtain better productive and economic yields through the practice of flowering induction. In this context, the objective of this work is to evaluate the effects of PBZ doses applied by irrigation system on the biochemical and physiological variables of 'Tommy Atkins' mango cultivar in comparison to the conventional method of application.

\section{MATERIAL AND METHODS}

The experiment was carried out in the orchard of Fazenda Special Fruit located at 9 ${ }^{\circ} 8,9^{\prime \prime} \mathrm{S}$, $40^{\circ} 18^{\prime} 33.6^{\prime \prime} \mathrm{W}$, and altitude of $373 \mathrm{~m}$, in the city of Petrolina, Pernambuco State, Brazil. The region's climate is classified as semiarid, BSwh' according to the Köppen classification. The relative humidity and the average annual temperature are $66 \%$ and $26.5^{\circ} \mathrm{C}$, respectively. The climatic data during the period of study are shown in Figure 1. Data were obtained from a meteorological station installed close to the experimental area.

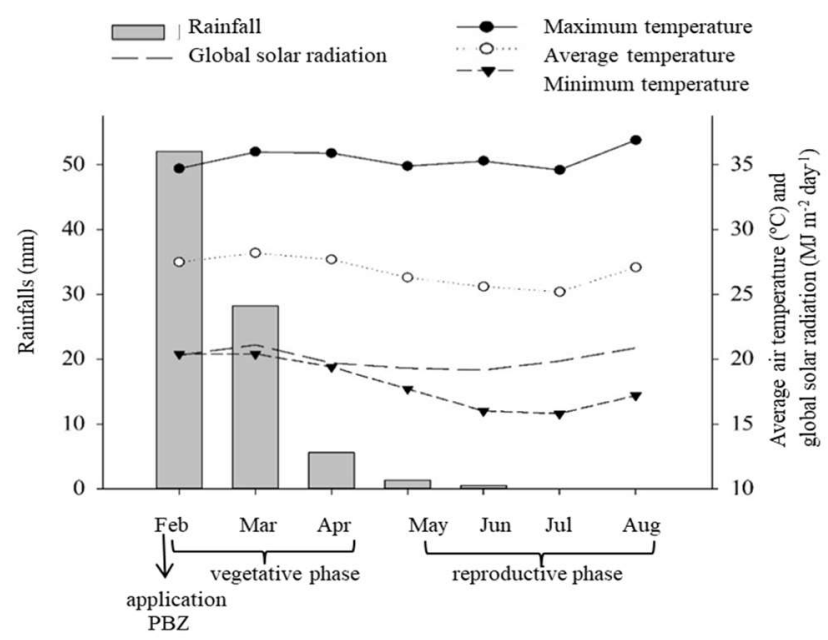

Figure 1: Rainfalls (mm), average air temperature $\left({ }^{\circ} \mathrm{C}\right)$ and global solar radiation $\left(\mathrm{MJ} \mathrm{m}^{-2}\right.$ day $\left.{ }^{-1}\right)$ recorded in Petrolina, Brazil, during the conduction of the experiment (February to August 2018).

Mango plants of the cultivar 'Tommy Atkins', with eight years of age, were used in a spacing of $3 \times 10 \mathrm{~m}$. The irrigation of the area was carried out by micro sprinklers installed next to the 
plant base. A commercial mango orchard was managed with pruning, weeding, fertilizing and phytosanitary treatments, as described by Mouco and Silva (2015) [2]. The source of PBZ used to aid floral induction was Cultar, a commercial product with $25 \%$ active ingredient (a.i.). The experimental design was randomized blocks in a $5 \times 2+1$ factorial design. The first factor was five paclobutrazol doses applied by irrigation $\left(0.5,1.0,1.5,2.0\right.$ and $2.5 \mathrm{~g} \mathrm{a.i.}^{-1}$, canopy linear); the second factor was two phenological phases of collection (vegetative/ march and flowering/ june), and an additional treatment (control) with the application of a dose in the conventional form (2.0 g a.i. ${ }^{-1}$ linear canopy applied manually by haul), and four replications. The plots consisted of four plants; the two central plants were considered useful.

Physiological and biochemical evaluations were carried out on leaf tissue at two phenological stages of the mango production cycle (vegetative and flowering). For the analysis of physiological responses related to gas exchange, physiologically mature leaves were exposed to the sun. Net photosynthesis (A), stomatal conductance (gs), transpiration (E) and leaf temperature (Tl) were analyzed by a gas exchange meter (IRGA, Li 6400 Licor $^{\mathbb{R}}$ ). Sampling was carried out at 30 and 120 days after the application of treatments between 10:00 am and 12:00 pm.

To determine biochemical characteristics, leaves were collected after physiological evaluations. The leaves were dehydrated in a forced air circulation oven at $60^{\circ} \mathrm{C}$ until they reached a constant weight. Subsequently, the samples were ground, soaked in a buffer solution and centrifuged to obtain the extract. This extract was used to determine total soluble sugars (TSS) according to the methodology described by Yemm and Willis (1954) [11], reducing sugars (RS) quantified by the dinitrosalicylic method (DNS) [12], total soluble proteins (TSP) following the method described by Bradford (1976) [13], and total amino acids (TAA) by the ninhydrin test using the methodology of Yemm and Coccking (1955) [14]. The levels of non-reducing sugars (NRS) were determined by the difference between total soluble sugars and the concentrations of reducing sugars.

The data were subjected to analysis of variance to compare the methods and doses of PBZ. The average values at the dose of $2.0 \mathrm{~g}$ a.i. ${ }^{-1}$ linear canopy applied by irrigation system and conventional application were compared at two plant phenological phases and submitted to the Tukey test $(5 \%)$. The doses applied by irrigation system were compared with the phenological phases of the plant and submitted to regression when significant (5\%). The analyses were performed using the SISVAR ${ }^{\circledR} 5.6$ software.

\section{RESULTS AND DISCUSSION}

By analyzing the variance of the factors studied, a significant interaction was observed between the forms of application of PBZ and the phenological phases of the crop for the characteristics total soluble sugars (TSS) and total amino acids (TAA). The levels of non-reducing sugars (NRS) were affected in isolation by the forms of application (Table 1).

Table 1: Total soluble sugars (TSS), total amino acids (TAA) and non-reducing sugars (NRS) in the mango leaf tissue ('Tommy Atkins' cultivar) in function of forms of application of PBZ and phenological phases. Petrolina, Brazil, 2018.

\begin{tabular}{|c|c|c|c|c|c|}
\hline & \multicolumn{2}{|c|}{ TSS $\left(m g \cdot g^{-1}\right)$} & \multicolumn{2}{|c|}{ TAA (umol g $\left.{ }^{-1} \mathrm{DM}\right)$} & \multirow{2}{*}{$\begin{array}{c}\mathrm{NRS} \\
\left(\mathrm{mg} \cdot \mathrm{g}^{-1}\right)\end{array}$} \\
\hline & Vegetative & Flowering & Vegetative & Flowering & \\
\hline Conventional & $6.04 \mathrm{aA}$ & $5.63 \mathrm{aA}$ & $5.07 \mathrm{bB}$ & $7.96 \mathrm{aA}$ & $3.23 \mathrm{a}$ \\
\hline Non-conventional & $5.57 \mathrm{aA}$ & $3.58 \mathrm{bB}$ & $9.45 \mathrm{aA}$ & $8.88 \mathrm{aA}$ & $2.07 \mathrm{~b}$ \\
\hline $\mathrm{CV} \%$ & \multicolumn{2}{|c|}{8.90} & \multicolumn{2}{|c|}{9.43} & 15.24 \\
\hline
\end{tabular}

Means followed by the same lowercase letter in each column do not differ by Tukey test at $5 \%$ probability. Means followed by the same uppercase letter in each line do not differ by Tukey test at $5 \%$ probability.

In relation to TSS, when using the conventional method (Table 1), there was no significant difference between the phenological phases. However, in the non-conventional method, there was a higher TSS content at the vegetative phase. There was no significant difference between the 
methods at the vegetative phase. In flowering, there is less TSS content when using the nonconventional system. This decrease may be because the application by irrigation system makes PBZ available in a better distributed way in the zone with the highest concentration of roots, where the root system is more active, thus promoting a more efficient assimilation of the product. As a result, PBZ increased the TSS content at the vegetative phase. During the flowering phase, there was a higher consumption of carbohydrates for the formation and development of panicles, resulting in lower TSS levels in leaves.

According to Saxena, Singh and Pathak (2014) [4], changes in the total sugar content may occur because of the increase in the levels of reducing sugars and the conversion of the insoluble fraction of the carbohydrate into soluble fraction during the differentiation of flower buds. Souza et al. (2016) [5], evaluating TSS levels in function of different forms of application of PBZ and phenological phases in 'Palmer' mango cultivar, observed that the forms of application did not exert a significant effect on this characteristic.

The levels of total amino acids during the vegetative phase were lower when using the conventional system (Table 1). However, during the flowering phase, no significant differences were observed between the application methods. By comparing the application methods, the conventional system promoted higher levels of TAA during flowering. However, when the nonconventional system was used, there were no statistical differences between the phenological phases of the culture. Saxena, Singh and Pathak (2014) [4] reported that during the reproductive phase of mango, there is a significant increase in the levels of amino acids in leaves, corroborating the results obtained in the present study. Tiwari, Patel and Pandey (2018) [15] stated that amino acids play an important role in the floral induction of mango trees because they are largely involved in primary and secondary metabolism, leading to the synthesis of various compounds that regulate flowering and contributing to the production and quality of fruits.

The highest levels of non-reducing sugars were observed when using the conventional system (control), which promoted an increase of $36 \%$ in relation to the non-conventional system. According to Koch (2004) [16], soluble sugars such as sucrose, glucose and fructose, are important substrates of metabolism that help plants in various events of their development and in their physiological processes, regulating the import of carbon into the metabolically active collector.

By evaluating the phenological phases of the culture regardless of the form of application, reducing sugars (RS), total soluble proteins (TSP), photosynthesis rate (A), stomatal conductance (gs) and leaf temperature (Tl) exerted significant effects (Table 2). The highest levels of RS, A, gs and $\mathrm{Tl}$ were obtained at the vegetative phase. During flowering, these variables decreased by $47 \%, 66 \%, 89 \%$ and $6.5 \%$, respectively. Conversely, TSP levels increased by $62 \%$ at this stage.

Table 2: Reducing sugars (RS), total soluble proteins (TSP), net photosynthesis (A), stomatal conductance (gs) and leaf temperature (Tl) at two phenological stages of 'Tommy Atkins' mango cultivar regardless of the application method. Petrolina/Brazil, 2018.

\begin{tabular}{cccccc}
\hline & $\mathrm{RS}$ & $\mathrm{TSP}$ & $\mathrm{A}$ & $\mathrm{Gs}$ & $\mathrm{Tl}$ \\
\cline { 2 - 6 } & $\left(\mathrm{mg} \mathrm{g}^{-1}\right)$ & $\left(\mathrm{mg} \mathrm{g}^{-1}\right)$ & $\left(\mu \mathrm{mol} \mathrm{CO} \mathrm{m}^{-2} \mathrm{~s}^{-1}\right)$ & $\left(\mathrm{mol} \mathrm{m}^{-2} \mathrm{~s}^{-1}\right)$ & $\left({ }^{\circ} \mathrm{C}\right)$ \\
\hline Vegetative & $3.24 \mathrm{a}$ & $0.44 \mathrm{~b}$ & $24.87 \mathrm{a}$ & $0.45 \mathrm{a}$ & $31.21 \mathrm{a}$ \\
Flowering & $1.72 \mathrm{~b}$ & $1.16 \mathrm{a}$ & $8.50 \mathrm{~b}$ & $0.05 \mathrm{~b}$ & $29.19 \mathrm{~b}$ \\
\hline $\mathrm{CV} \%$ & 11.44 & 7.19 & 15.98 & 16.40 & 1.55 \\
\hline
\end{tabular}

Means followed by the same letter in each column do not differ by Tukey test at $5 \%$ probability.

According to Davenport (2007) [9], the levels of carbohydrates in leaves are involved with the development of the panicle and in the intensity of flowering induction. Therefore, the reduction of both total soluble sugars and reducing sugars during the flowering phase may have occurred due to energy demand to form the inflorescences. Working with 'Ataulfo' mango, SantosVillalobos et al. (2013) [17] observed that the levels of carbohydrates decreased with time, suggesting that they were consumed to originate panicles and to promote their development. Urban, Lu and Thibaud (2004) [18] reported that a marked reduction in the levels of reducing 
sugars in leaves during flowering may occur because most of the carbohydrate reserve is used during the flowering process.

The higher photosynthetic rate, stomatal conductance and leaf temperature at the vegetative phase can be associated with climatic data. Taiz et al. (2017) [19] report that without water stress, the warm season tends to promote an adjustment in stomatal conductance and, consequently, a higher photosynthetic rate, as shown in Table 2. Souza et al. (2016) [5] evaluating the effects of the phenological phases on the physiological variables of 'Palmer' cultivar mango, observed that the highest values of photosynthesis rate were found at the flowering phase, his being the hottest period of the physiological assessment of work.

The greater accumulation of total soluble proteins at the flowering phase evidences the higher transport of photoassimilates during this phase. The results confirmed that there is an intense mobilization of leaf proteins to flower buds at the bud emission stage, which occurs in order to sustain the high protein demand during flowering. A higher protein accumulation during floral initiation was also observed by Urban, Lu and Thibaud (2004) [18]. According to these authors, this increase can create conditions that stimulate flowering.

For the analyzed variables, no interactions $(p<0.05)$ were observed between the phenological phases and the doses applied by irrigation system, evidencing that the doses of PBZ provided the same effects on plants regardless of the phase. Regarding the phenological phases (Table 3), carbohydrate levels were more affected at the flowering phase: there was a reduction of $52 \%$ in $\mathrm{RS}$ and 35\% in TSS. However, the levels of total soluble proteins were higher during the flowering phase, presenting an increase of $56 \%$.

Table 3: Total soluble sugars (TSS), reducing sugars (RS), total soluble proteins (TSP), net photosynthesis (A), stomatal conductance (gs) and leaf temperature (Tl) at two phenological stages of 'Tommy Atkins' mango cultivar regardless of doses applied by irrigation system. Petrolina/Brazil, 2018.

\begin{tabular}{|c|c|c|c|c|c|c|c|}
\hline & TSS & $\mathrm{RS}$ & TSP & $\mathrm{A}$ & Gs & $\mathrm{E}$ & $\mathrm{Tl}$ \\
\hline & $\left(\mathrm{mg} \mathrm{g}^{-1}\right)$ & $\left(\mathrm{mg} \mathrm{g}^{-1}\right)$ & $\left(\mathrm{mg} \mathrm{g}^{-1}\right)$ & $\begin{array}{l}\left(\mu \mathrm{molCO}_{2}\right. \\
\left.\mathrm{m}^{-2} \mathrm{~s}^{-1}\right)\end{array}$ & $\left(\mathrm{mol} \mathrm{m} \mathrm{m}^{-2} \mathrm{~s}^{-1}\right)$ & 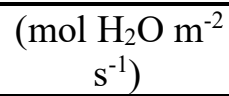 & $\left({ }^{\circ} \mathrm{C}\right)$ \\
\hline Vegetative & $5.62 \mathrm{a}$ & $3.33 \mathrm{a}$ & $0.47 \mathrm{~b}$ & $23.77 \mathrm{a}$ & $0.53 \mathrm{a}$ & $2.53 \mathrm{a}$ & $30.77 \mathrm{a}$ \\
\hline Flowering & $3.66 \mathrm{~b}$ & $1.60 \mathrm{~b}$ & $1.08 \mathrm{a}$ & $9.78 \mathrm{~b}$ & $0.07 \mathrm{~b}$ & $1.98 \mathrm{~b}$ & $29.77 \mathrm{~b}$ \\
\hline $\mathrm{CV} \%$ & 14.14 & 9.82 & 11.13 & 14.57 & 13.31 & 12.62 & 2.46 \\
\hline
\end{tabular}

Means followed by the same letter in each column do not differ by Tukey test at $5 \%$ probability.

This reduction in TSS and RS levels during the flowering phase, may have probably occurred due to the beginning of translocation of the carbohydrates necessary for the formation of panicles, using total soluble sugars and reducing sugars for respiration and synthesis of essential molecules for flowering. These results corroborate with those described by Bolding, Smith and Klages (2000) [20], who reported that the consumption of carbohydrates usually occurs during the sprouting and flower emission in the cultivation of mango. Singh and Rajan (2009) [21], evaluating the variation of commercial mango cultivars in terms of photosynthesis production and translocation efficiency, also observed lower levels of TSS and RS during the beginning of flowering.

The greater accumulation of proteins at the flowering stage may be due to their accelerated mobilization to form flower buds. The segmentation and channeling of low molecular weight protein from the source (leaves) to the drains is known to be easier when its molecular weight is higher [22]. Therefore, increasing the mobilization of low molecular weight proteins can be one of the aids of paclobutrazol to improve flowering of mango trees [4].

The highest values of gas exchange were found at the vegetative phase. There were decreases of $59 \%$ in the photosynthetic rate, $87 \%$ in stomatal conductance, $3 \%$ in transpiration rate, and $22 \%$ in leaf temperature during flowering (Table 3). In addition, stomatal conductance, transpiration rate and leaf temperature followed a similar tendency as photosynthesis rate, evidencing a high correlation with the phenomenon of stomatal opening and closing. This reduction in gas exchange during the flowering phase may be related to decreases in air 
temperature (Figure 1). A greater photosynthetic efficiency promotes a greater accumulation of carbohydrates, which can contribute significantly to flowering, fruiting and fruit production [23]. Singh et al. (2017) [24], studying the effects of PBZ on the physiological characteristics of lychee, also reported higher A, E and gs during the vegetative phase when compared to the flowering stage. According to the authors, this can be attributed to the beginning of recovery from plant exhaustion due to the heavy load of the season harvest.

By evaluating the levels of total soluble sugars in function of doses of PBZ applied by irrigation system (Figure 2A), the increase in the dose of PBZ promoted a significant increase in the levels of TSS. The highest content of total soluble sugars $\left(6.0 \mathrm{mg} \cdot \mathrm{g}^{-1}\right)$ was found by applying the highest dose of PBZ (2.5 g a.i. ${ }^{-1}$ linear canopy), while the lowest content $\left(3.69 \mathrm{mg}^{-\mathrm{g}^{-1}}\right)$ was observed by applying the lowest dose ( $0.5 \mathrm{~g}$ a.i. ${ }^{-1}$ linear canopy).
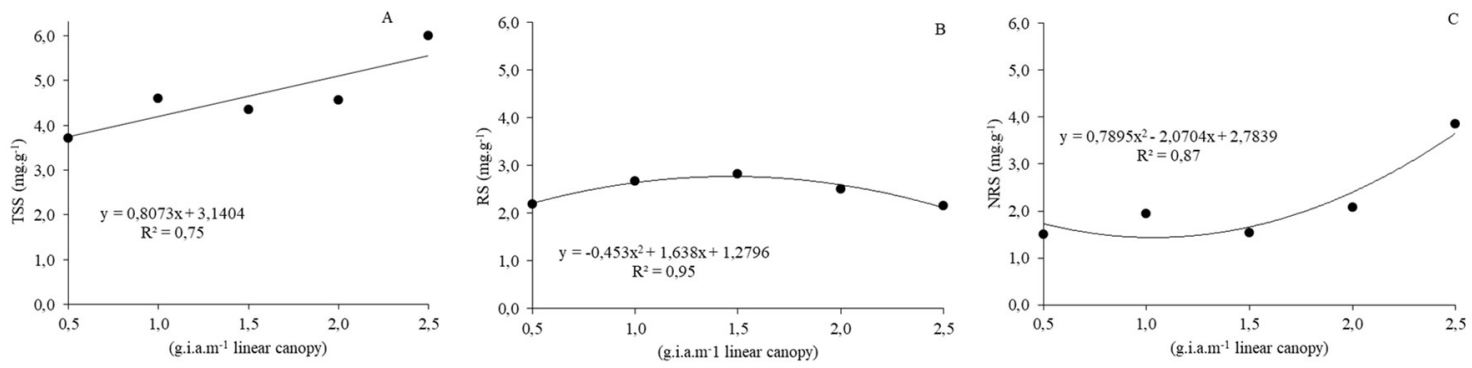

Figure 2: (A) - Total soluble sugars (TSS), (B) - reducing sugars (RS) and (C) - non-reducing sugars (NRS) in the mango leaf tissue ('Tommy Atkins' cultivar) in function of doses of PBZ applied by irrigation system. Petrolina/Brazil, 2018.

This increase in total soluble sugar content may be an effect of the decrease in gibberellins content by PBZ, as reported by Upreti et al. (2014) [25]. According to the authors, gibberellins promote the breakdown of carbohydrates to sustain vegetative growth and as PBZ acts as an inhibitor of gibberellin biosynthesis, the levels of inhibited gibberellins consequently contributed to the increase in carbohydrate levels. Saxena, Singh and Pathak (2014) [4] in a study on 'Amparali' mango, also reported an increase in total sugar levels in response to the treatment with PBZ, corroborating the results of the present study.

In relation to reducing sugars, there was an increase in levels due to the increase in the doses of PBZ up to the maximum dose of $1.8 \mathrm{~g}$ a.i. ${ }^{-1}$ linear canopy, which was equivalent to $2.76 \mathrm{mg} . \mathrm{g}^{-}$ ${ }^{1}$. These results show that the application of PBZ significantly influences the leaf carbohydrate balance.

These results disagree with those found by Souza et al. (2016) [5], who observed a linear reduction in the content of reducing sugars in response to the application of PBZ by irrigation system; the lowest content $\left(1.31 \mathrm{mg} \cdot \mathrm{g}^{-1}\right)$ was found by applying $1.9 \mathrm{~g}$ a.i. ${ }^{-1}$ linear canopy. Regarding NRS levels, the authors also found a quadratic response, in which the highest level was $14.32 \mathrm{mg} . \mathrm{g}^{-1}$, observed by applying $1.0 \mathrm{~g} \mathrm{a.i.} .^{-1}$ linear canopy.

By evaluating the influence of PBZ doses on non-reducing sugar levels (Figure 2C), the levels fitted the quadratic model, where the lowest NRS content $\left(1.42 \mathrm{mg} . \mathrm{g}^{-1}\right)$ was observed by applying $1.3 \mathrm{~g}$ a..$^{-1}$ linear canopy. Then, there was an increase in the levels of non-reducing sugars as the concentrations of PBZ increased.

Oliveira et al. (2013) [26], evaluating the relation between reproductive development and the concentration of carbohydrates in leaves of olive plants by the application of PBZ, observed a linear increase in the levels of NRS as the doses increased. According to these authors, this behavior is probably related to the lower vegetative growth of plants due to the PBZ applications. Therefore, it can be stated that less sucrose was converted into glucose and fructose (reducing sugars) through the hydrolysis of groupings to which they are interconnected.

According to Figures $3 \mathrm{~A}$ and $3 \mathrm{~B}$, both the amino acids and total soluble proteins contents showed a quadratic behavior with increase of PBZ. As amino acids are precursors of proteins, there is an increase in proteins with the increase in amino acids. Regarding the contents of total amino acids, the maximum value $\left(9.10 \mathrm{umol} \mathrm{g}^{-1} \mathrm{DM}\right)$ was obtained for the dose $1.8 \mathrm{~g}$ a.i. ${ }^{-1}$ linear 
canopy. Regarding the total soluble protein content, the highest value was found for the dose 1.8 g a.i. ${ }^{-1}$ linear canopy, which corresponded to $0.81 \mathrm{mg} . \mathrm{g}^{-1}$. Saxena, Singh and Pathak (2014) [4] reported that the soluble protein content in leaves gradually decreased with increasing PBZ concentrations; the maximum decrease was noted at $8 \mathrm{~g}$ a.i. per $\mathrm{m}^{2}$. Anusuya et al. (2018) [27], studying the 'Bangalora' cultivar using different concentrations of PBZ, reported that the maximum total soluble protein content $\left(13.96 \mathrm{mg} \mathrm{g}^{-1}\right)$ was recorded in plants treated with $0.75 \mathrm{~g}$ a.i. per $\mathrm{m}^{2}$.
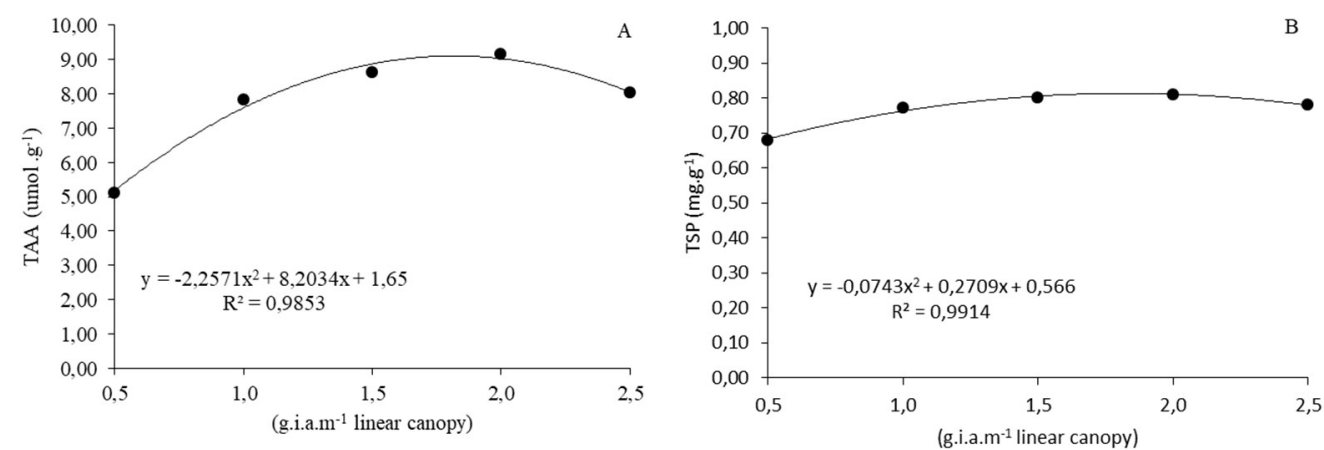

Figure 3: (A) - Total amino acids (TAA) and (B) - 1otal soluble proteins (TSP) in the mango leaf tissue ('Tommy Atkins' cultivar) in function of the application of paclobutrazol by irrigation. Petrolina/Brazil, 2018.

Regarding the physiological characteristics, the increase in PBZ doses promoted a linear decrease in photosynthesis rate and in stomatal conductance (Figures 4A and 4B). However, it significantly increased leaf temperature (Figure 4C). The increase in concentrations of PBZ provided a decrease of $36 \%$ in photosynthesis rate and $47 \%$ in stomatal conductance in relation to the average of the lowest dose. The lowest rate of photosynthesis $\left(13.21 \mu \mathrm{mol} \mathrm{CO} \mathrm{Cm}^{-2} \mathrm{~s}^{-1}\right)$ and stomatal conductance $\left(0.21 \mathrm{~mol} \mathrm{H}_{2} \mathrm{O} \mathrm{m}^{-2} \mathrm{~s}^{-1}\right)$ were verified by applying the highest dose of PBZ. Probably, this decline in photosynthesis rate is related to the decrease in stomatal conductance and the increase in leaf temperature due to the increase in applied doses. Chaves et al. (2002) [28], report that the reduction in stomatal conductance promoted a decrease in gas exchange between plants and the atmosphere, promoting an increase in leaf temperature, in addition to impairing the absorption of atmospheric $\mathrm{CO}_{2}$, directly influencing the photosynthesis of plants.

Souza et al. (2016) [5], stated that the increase in PBZ doses promotes stomatal closure, which is an adaptive mechanism of plants to avoid excessive water losses, especially under stress conditions.
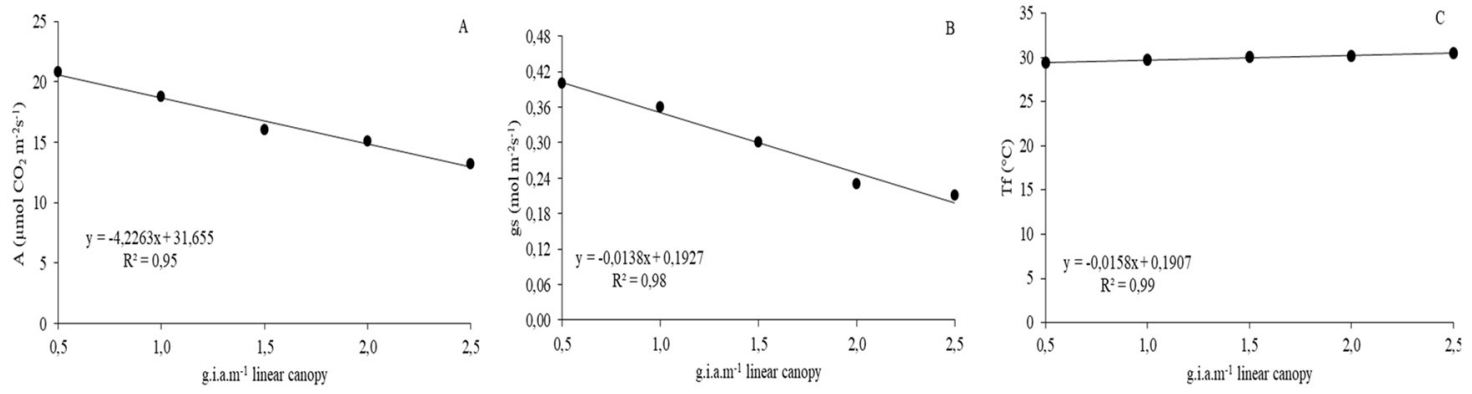

Figure 4: (A) - Photosynthesis rate (A), (B) - stomatal conductance (gs) and (C) - leaf temperature (Tl) of mango (cultivar Tommy Atkins) in function of the application of paclobutrazol by irrigation. Petrolina/Brazil, 2018. 


\section{CONCLUSIONS}

The application of paclobutrazol by irrigation system is more efficient than the conventional application, allowing a greater assimilation of the product by the plant and the reduction of the dose. Lower doses of PBZ induce better physiological responses in the 'Tommy Atkins' mango cultivar.

\section{REFERENCES}

1. Benno Bernardo Kist et al. Anuário Brasileiro De Fruticultura. Santa Cruz do Sul: Editora Gazeta Santa Cruz; 2018. 88 p. Available from: http://www.editoragazeta.com.br/sitewp/wpcontent/uploads/2018/04/FRUTICULTURA_2018_dupla.pdf

2. Mouco MAC, Silva DJ. Mangicultura: produção de qualidade ganha mercados no Brasil e no exterior. Cadernos do Semiárido: Riquezas e Oportunidades. 2015;4:20-23.

3. Upreti KK, Reddy YTN, Prasad SRS, Bindu GV, Jayarama HL, Rajan S. Hormonal changes in response to paclobutrazol induced early flowering in mango cv. "Totapurie". Sci Hort. 2013;150:414-418, doi: 10.1016/j.scienta.2012.11.030.

4. Saxena P, Singh VK, Pathak N. Antioxidative enzymes and biochemical changes in paclobutrazol induced flowering in mango (M. indica) cultivars. J Environm Biol. 2014;35(6):1061-1066.

5. Souza MA, Mesquita AC, Simoes WL, Ferreira KM, Araújo EFJ. Physiological and biochemical characterization of mango tree with paclobutrazol application via irrigation. Pesq Agropec Trop. 2016;46(4):442-449, doi: 10.1590/1983-40632016v4642829.

6. Albuquerque JAS, Medina VD, Mouco MA do C. Indução floral. In: Genu PJC, Pinto CAQ, editors. A cultura da mangueira. Brasília (DF): Embrapa Informação Tecnológica; 2002. p. 259-276.

7. Mouco MA do C, Ono EOO, Rodrigues JD. Mango flower induction in the Brazilian Northeast Semiarid with gibberellin synthesis inhibitors. Acta Hortic. 2010;884:591-596, doi: 10.17660/ActaHortic.2010.884.77.

8. Souza MA, Simoes WL, Mesquita AC, Mouco MAC, Cavancante BLS, Guimarães MJM. Manejo da quimigação para indução floral da mangueira 'Palmer' no Submédio do Vale do São Francisco. Irriga, 2018;23(3):442-453, doi: 10.15809/irriga.2018v23n3p442-453.

9. Davenport TL. Reproductive physiology of mango. Braz J Plant Physiol. 2007;19(4):363-376, doi: 10.1590/S1677-04202007000400007.

10. Wongsrisakulkaew Y, Boonprakob U, Sethpakdee R, Juntawong N. Effect of paclobutrazol concentrations and time of foliar application on flowering of 'Namdokmai-sitong' mango. Int $\mathrm{J}$ Geomate. 2017;12(30):41-45, doi: 10.21660/2017.30.96545.

11. Yemm EW, Willis AJ. The estimation of carbohydrates in plant extracts by anthrona. Biochem J. 1954;57(3):508-514, doi: 10.1042/bj0570508.

12. Miller EL. Use of dinitrosalicylic and reagent determination of sugar. Anal Chem. 1959;31(3):426-428, doi: $10.1021 / \mathrm{ac} 60147 \mathrm{a} 030$.

13. Bradford MM. A rapid and sensitive method for the quantification of microgram quantities of protein utilizing the principle of protein-dye binding. Anal Biochem. 1976;72(1-2):248-258, doi: 10.1016/00032697(76)90527-3.

14. Yemm EW, Cocking EC. The determination of amino acids with ninhydrin. Analyst. 1955;80:209-213.

15. Tiwari DK, Patel VB, Pandey AK. Floral induction in mango: physiological, biochemical and molecular basis. Int J Chem Stud. 2018;6(1):252-259.

16. Koch K. Sucrose metabolism: regulatory mechanisms and pivotal roles in sugar sensing and plant development. Curr Opin Plant Biol. 2004;7:235-246, doi: 10.1016/j.pbi.2004.03.014.

17. Santos-Villalobos SL, Folter S, Délano-Frier JP, Gómez-Lim MA, Guzmán-Ortiz DA, Peña-Cabriales JJ. Growth promotion and flowering induction in mango (Mangifera indica L. cv "Ataulfo") trees by burkholderia and Rhizobium inoculation: morphometric, biochemical, and molecular events. J Plant Growth Regul. 2013;32(3):615-627, doi: 10.1007/s00344-013-9329-5.

18. Urban L, Lu P, Thibaud R. Inhibitory effect of flowering and early fruit growth on leaf photosynthesis in mango. Tree Physiol. 2004;24:387-399, doi: 10.1093/treephys/24.4.387.

19. Taiz L, Zeiger E, Moller IM, Murphy A. Fisiologia e desenvolvimento vegetal. $6^{\mathrm{a}}$ ed. Porto Alegre: Artmed, 2017. $858 \mathrm{p}$.

20. Bolding H, Smith GS, Klages K. Seasonal concentration of nonstructural carbohydrates of five Actinidia species in fruit, leaf and fine root tissue. Ann Bot. 2000;85(4):469-476, doi: 10.1006/anbo.1999.1094.

21. Singh VK, Rajan S. Changes in photosynthetic rate, specific leaf weight and sugar contents in mango (Mangifera indica L.). Open Hort J. 2009;2:40-43, doi: 10.2174/1874840600902010040. 
22. Singh VK, Kumari S. Changes in biochemical and mineral constituents associated with jelly seed in mango (Mangifera indica) cv. 'Dashehari'. Indian J Agric Sci. 2011;81(6):563-566.

23. Sarker BC, Rahim MA. Influence of paclobutrazol on growth, yield and quality of mango. Bangladesh. J Agric Res. 2018;43(1):1-12, doi: 10.3329/bjar.v43i1.36154.

24. Singh SK, Kumar A, Pandey S, Nath V. Physio-biochemical status of shootsrelated to litchi flowering. Int J Advan Biol Biomed Res. 2017;7(1):185-189.

25. Upreti KK, Shivu Prasad SR, Reddy YTN, Rajeshwara AN. Paclobutrazol induced changes in carbohydrates and some associated enzymes during floral initiation in mango (Mangifera indica L.) cv. Totapuri. Indian Plant Physiol. 2014;19:317-323, doi: 10.1007/s40502-014-0113-8.

26. Oliveira DL, Cruz MCM, Oliveira AF, Chalfun NNJ, Alvarenga AA. Teores de carboidratos e indução do florescimento em mudas de oliveira submetidas a aplicação de paclobutrazol. Sci Agr Paranaensis. 2013;12(3):221-226, doi: 10.18188/sap.v12i3.5226.

27. Anusuya R, Vijayakumar RM, Srividhya S, Sivakumar R. Comparison of physiological and flowering parameters of main and off season by using different plant nutrients and growth hormone in mango (Mangifera indica L.) cv. Bangalora. J Agric Ecol. 2018;5:76-82.

28. Chaves MM, Pereira JS, Maroco J, Rodrigues ML, Ricardo CPP, Osório ML, Carvalho I, Faria T, Pinheiro C. How plants cope with water stress in the field. Photosynthesis and growth. Ann Bot. 2002;89:907-916, doi: 10.1093/aob/mcf105. 